\title{
Consensus Building among Multi-stakeholders in Intercity Cooperation: Drivers and Challenges in the Case of Kitakyushu and Davao
}

\author{
Larissa de Miranda Alem \\ Associate at the Institute of Law, Creative Arts, and Economy \\ Benjamin Hunnicutt Street 34, Parque Jabaquara. São Paulo, Brazil \\ Tel: 55-119-9205-6811Ｅ-mail: larissaalem@gmail.com
}

Received: October 1, 2020 Accepted: October 20, 2020 Published: October 30, 2020

doi:10.5296/emsd.v9i4.17762ＵRL: https://doi.org/10.5296/emsd.v9i4.17762

\begin{abstract}
Cities emerged as international agents and started engaging in intercity cooperation as a mechanism to address global challenges through regional solutions and also join resources to tackle local challenges and fulfill their management responsibilities. Collaborative planning to improve environmental conditions is one of the possible scopes for international cooperation, as stakeholders can share multiple information, knowledge, technologies, and governance experience. However, despite the benefits in a multi-stakeholder scheme, building consensus in such a diversified setting is a complex, time-consuming process, to reach a shared understanding about a certain problem and possible ways to address it.

During the last decade, the Japanese government, one of the largest world's donors of gross ODA, has been increasing the funding activities to promote intercity collaboration for the development of more sustainable societies, engaging multiple stakeholders for a wide diversity of projects. This research had selected three international projects in Davao, supported by Kitakyushu, and identified four groups of major drivers and challenges (communication, political and institutional, financial, and technical) that can either foster or hinder consensus building among multi-stakeholders in the context of intercity cooperation for collaborative environmental planning.
\end{abstract}

Keywords: Consensus building, Collaborative planning, Multi-stakeholders, Intercity cooperation, Environmental management

\section{Introduction}

International cooperation has long been an important instrument to build up the relationships 
between countries. Throughout history, countries' motivation for engaging in international partnerships has evolved from war reconstruction, friendship development, and cultural exchange to capacity building, economic development, and social improvement (De Villiers, 2009). The emergence of human rights, international goals, and a global agenda for development from the 1980s have established a favorable setting for the empowerment of more diversified actors of international cooperation, such as private agents, non-governmental organizations, and, of course, local governments.

The empowerment of cities as agents of international cooperation was a phenomenon that developed along with environmental policy expansion, as the 1980s were also a moment of rapid growth environmental awareness in a globalized context. Cities have been undertaking an increasing role in addressing the so-called global challenges through local solutions. However, this responsibility frequently faces several challenges, as most local governments, especially in developing countries, lack resources for consistent environmental policies, or are often dependent on national regulations and incentives (Fuhr et al., 2018).

In this sense, intercity cooperation has emerged for its fair potential to address many of those challenges, allowing cities to comply with their responsibilities. City-to-city cooperation can be understood as "all possible forms of relationship between local authorities at any level in two or more countries which are collaborating over matters of mutual interest, whether with or without external support" (United Nations Human Settlements Programme, 2001, p. 6). Therefore, intercity cooperation can establish a setting for resource exchange, including financial resources, technology, and capacity-building, according to local needs and capacities. For environmental management, cities can improve their regulatory capacity for local legislation development, their institutional capacity for providing environmental services, and their policy capacity to address local issues (Memon et al., 2005).

There are at least two great advantages of the international cooperation framework at the local level. First, local governments are closer to local stakeholders and more likely to be aware of local needs, priorities, strengths, and limitations, so collaboration actions can be quicker and better-targeted than national governments' (Ishinabe, 2010; Schreurs, 2010). Second, intercity cooperation has been presenting more tangible outcomes for stakeholders, compared with collaboration at the national level, because cities with similar experiences or characteristics can approach while avoiding conflicting higher national interests (Kurniawan et al., 2013).

In the past five years, major international agreements endorsed the importance of international cooperation as a mechanism to promote sustainable development solutions, not only among national governments, but also at other levels of governance, such as the United Nation' 2030 agenda and its 17 Sustainable Development Goals for a better life quality, that includes partnerships as a strategy to support the other goals (United Nations, 2020), and the Paris Agreement, that encourages regional and international cooperation to mobilize climate action with inclusion of multiple stakeholders (United Nations Framework Convention on Climate Change, 2015).

A common setting for international cooperation is North-South cooperation, known as the 
collaboration activities between developed and developing countries. Traditional international cooperation was criticized for the absence of long-term planning, for imposing the developed countries' visions and priorities on developing countries, and for the unequal relationship between agents (Rossel et al., 2007). However, there is a worldwide trend of shifting the pattern of North-South cooperation and the objective of countries' Official Development Assistance (ODA), with a focus on support for growth instead of direct assistance for poverty reduction, on multilateral assistance instead of bilateral assistance, and public-private partnership instead of transfer of public funds (Sawada, 2014). North-South cooperation between cities has a great potential to bridge technical and financial gaps that are sometimes necessary for technology transfer from developed to developing countries (Kurniawan et al., 2013), and to strengthen governance in developing cities by exchanging know-how and experience for improvement local administration, service provision and response capacity to local demands (Bontenbal, 2009).

Japan is one prominent example of national involvement in international cooperation and, as of 2017, it was the fourth-largest donor in the world. Japan's international cooperation history, from the 1950s until today, has moved from the position of receiver and provider of ODA (Ohno, 2013), which can be of great experience in supporting its developing country partners (Huda, 2016; Ministry of Foreign Affairs of Japan, 2004). Over the years, the country faced various periods of ODA organization and expansion (Yanagihara, 2017; Kato, 2016; Huda, 2016), but nowadays, the Japanese government is being internally pressured to reduce the ODA budget due to current fiscal constraints (Sawada, 2014; Nakamura \& Elder, 2012).

Over the years, Japanese local governments also became important agents of international collaboration activities. Although participating in cooperation is voluntary, cities like Kitakyushu, Yokohama, and Osaka are quite interested in promoting environmental technology transfer or low-carbon societies in cities overseas (Akagi et al., 2018), which raises the question of what motivations attract them to such time and resource-consuming activities.

There are many reasons behind such engagement. First, the Japanese local governments take the role of supporting the national government strategy on international cooperation, connecting domestic to the international level (Ishinabe, 2010; Takao, 2017). Second, Japanese cities have been struggling with their shrinking population and saturated domestic market, so collaboration activities offer a possibility of mutual gain (win-win), as Japan provides ODA, but is also able to develop joint research, to promote capacity-building to human resources, to explore new markets and business opportunities abroad, and to enhance available technologies (Akagi et al., 2018; Ohno, 2014; Nakamura, 2010). Third, the Japanese government has been promoting more multi-stakeholder governance schemes, with the inclusion of NGOs, universities, and the private sector; especially in the context of economic revitalization, companies and technology providers are also included in the process (Sawada, 2014; Ohno, 2014; Kato, 2016).

Past literature revealed that socioeconomic factors, such as exports, foreign residents, and fiscal capacity, are not necessarily major causes to involvement with international 
collaboration activities, but there are materialistic motivations to get involved, such as the incentive to environmental-related businesses, and idealistic motivations, such as the environmental protection as a globally shared responsibility (Nakamura et al., 2010). Pioneering, policy learning and innovation, and political leadership were also considered important drivers for successful engagement in international cooperation (Takao, 2014). One example that has merged all of these motivations is Kitakyushu.

Kitakyushu is one of the most active Japanese cities in terms of international intercity cooperation. The city was created in 1963, on Kyushu island, by the sea, in a favorable geographical position to exchange with foreign countries. During the first half of the 20th century, Kitakyushu's steel manufacturing was the main contributor to Japanese economic development and, in the 1960s, it was one of the four largest industrial zones in Japan (Takao, 2014). The city became heavily polluted and, before the general public was aware of all environmental and health damage, the air pollution colors were called "rainbow of smoke", a symbol of progress and economic development (Akagi et al., 2018).

However, in the 1970s, the city confronted serious hardships, with the economic slowdown due to the "iron chilling" (a decrease in the steel output, triggered by the oil crisis in 1973) and the environmental damage caused by the industry, such as air and sea pollution, and massive waste production (Akagi et al., 2018). The rising protests against this situation started with civil society. Kitakyushu's mothers, under the slogan "We Want Our Blue Sky Back", led campaigns, supported by university professors, to push Kitakyushu private companies and the local government to address the problem. Eventually, the so-called "sea of death" in Dokai Bay was dredged, cost $71 \%$ borne by Kitakyushu business sectors and 29\% by the municipal government, and a pollution act was enacted (Takao, 2014).

The experience of partnerships with various sectors of society, with environmental governance and with new environmental technologies and industries granted Kitakyushu a worldwide recognition: the city received a wide range of awards, such as the "Global 500 Award", from United Nations Environment Programme, the "Green Growth City" by OECD's Green City Program, and the "1st Japan SDGs Award” (Akagi et al., 2018; Takao, 2014). The history of overcoming such serious environmental damage became a reference for cities in developing countries with similar struggles and the first step into the city's active engagement in international cooperation (Akagi et al., 2018).

Through the years, Kitakyushu organized sections and institutions to support international cooperation for environmental activities. The Kitakyushu Urban Centre from the Institute for Global Environmental Strategies (IGES-KUC), established in 1999, is responsible for conducting research and activities for waste management, low-carbon cities, and Sustainable Development Goals, to support sustainable cities initiatives in Asian countries. The Kitakyushu International Techno-co-operative Association (KITA), founded in 1980, provides technical expertise and promoting international cooperation, to conciliate industrial development and environmental conservation. The JICA Kyushu Center, established in 1989, hosts foreign participants in the Co-Creation Program and for conducting diverse partnerships, such as grassroots technical cooperation activities. The International Environmental 
Cooperation, office under the Environmental Bureau of the city government, was established in 2000. The Asian Center for Low-Carbon Society (AJITE), established in 2010, supports local companies in pursuing low carbon-related business in Asia and promote joint operation between the Kitakyushu City government, the KITA, and the IGES-KUC.

By the time of this research, one of Kitakyushu's international partners was Davao, the largest city in the Philippines, with over 1.5 million people and an area of almost $4.000 \mathrm{~km}^{2}$. As many developing cities, Davao has been struggling with the side effects of development and large industrialization over the environment. Since 2017, two schemes of international cooperation were being conducted between the two cities, for the development of more sustainable practices in Davao: the first scheme was the JICA Grassroots Project for Enhancing Solid Waste Management in Davao City; and the second was the City-to-City (C2C) Collaboration Programme for Low-Carbon Society, which comprised of one project for implementation of LED streetlights and one project for the development of a Local Climate Change Action Plan in Davao.

For both schemes, the complexity and scale of the projects demanded the participation of a wide range of stakeholders at many levels, such as National Governments' representatives, the local governments' officials, private companies' agents, NGOs' members, and others actors (citizens, universities, research institutes), each of them with their capacities, limitations, interests, and priorities. Therefore, collaborative activities require a certain extent of understanding and agreement between these stakeholders. For this purpose, stakeholders must be able to express their views to work on the so-called consensus building.

Consensus building is a concept brought by different authors, with diverse perceptions of what it means to reach consensus and what are the characteristics of is this process. However, the literature agrees that consensus is essentially built with open communication among stakeholders, meaning that involved actors must have the opportunity to present their perspectives in the process. Therefore, intercity cooperation, as a process that is likely to attract multiple stakeholders to collaborative planning, also requires proper communication between them. A successful intercity scheme is the one able to bring stakeholders to an open discussion and joint analysis, implementation, and evaluation of strategies (Buis, 2009), associated with free flows of information, reciprocity, understanding, and leadership (Tjandradewi \& Marcotullio, 2008). Therefore, this research understands consensus building as a process of collaborative planning that requires the participatory dialogue of involved stakeholders, as well as the effort to reach a common understanding of the problem to be addressed and potential solutions.

Consensus building is a demanding and time-consuming process that requires skilled people for the role of facilitation (Innes, 2004). Even before considering the challenge of working with various interests and priorities, the context already poses influences over consensus building, especially in international cooperation. Context-related obstacles might include

\footnotetext{
${ }^{1}$ For further information on consensus building and collaborative planning concepts, check Susskind (1999), Carpenter (1999), Innes \& Booher (1999), Innes \& Connick (2001), Connick \& Innes (2001), Susskind et al. (2002), Innes (2004), Booher (2005), Gunton et al. (2006), Susskind, Camacho, and Schenk (2010), Margerum (2011), Morse \& Stephens (2012), and Margerum (2012).
} 
different perceptions of the problems and potential solutions; diverse social settings, legal conditions, political dynamics, and organizational cultures; and multiple ethnic, racial, religious, language, or economic backgrounds (Margerum, 2002; Carpenter, 1999; Ayala-Orozco et al., 2018). Communication and dialogue might be hindered due to uneven information distribution in multi-stakeholder schemes (Ayala-Orozco et al., 2018) and uneven power distribution between actors, which might create situations of co-opted agreement, manipulated consensus, or pressure over dissenters (Markopoulos, 2012; Cullen, et al., 2010). Last, but not least, consensus-building processes face the "two table problem", meaning that stakeholders must build consensus not only in the stakeholders' table but also within their organization (Margerum, 2008).

If consensus building is such a challenging, long process, what motivations bring stakeholders to engage in consensus building processes? First, consensus building is a useful mechanism to reach a common understanding in the context of a controversial problem, as it favors mutual learning (Innes, 2011). Since stakeholders are committed to establishing open participatory communication, actors are likely to gather and share multiple information to improve common agreement (Connick \& Innes, 2001; Cullen et al., 2010), which also contributes to trust-building, social and political capital development, and relationship improvement (Gunto et al., 2006; Connick \& Innes, 2001; Cullen et al., 2010). Besides, the participation of multiple stakeholders fosters the development of formal and informal networks (Innes, 2011), improves the connection of nongovernmental stakeholders to public policymakers (Susskind et al., 2002). Moreover, consensus building will not necessarily be halted or inhibited in cross-cultural negotiations, as the willingness to negotiate can overcome cultural barriers (Liu et al., 2012). Consensus building allows stakeholders to target problems that are beyond the power of a single individual or stakeholder to solve by itself (Innes, 2004) and it can be adjusted and framed to particular circumstances and contexts (Carpenter, 1999).

Past literature well presented the role of Japanese cities in Japan's national strategy for international cooperation, and what is the favorable context that encourages these local governments to engage in intercity collaboration activities. Previous studies have also widely discussed the benefits and challenges in collaborative planning and consensus-building processes in multi-stakeholders' schemes. Nevertheless, few previous studies addressed the intersection of these research topics, especially what key factors interfere with consensus building in an international intercity cooperation.

Hence, to tackle this gap, this research inquires what elements can foster or hinder the consensus-building process among the multi-stakeholders in the context of intercity cooperation for environmental planning. For that purpose, the objective of this research was to analyze what drivers and challenges emerged in three collaboration projects between Kitakyushu and Davao, which will be described with further details in the next session.

\section{Methods and Methodology}

\subsection{Case Study}

The proximity between Japan and the Philippines has started from the historical relocation of 
a great number of Japanese companies to the latter, integrating its economic development strategy. Since 1968, along with the development of the Philippine-Japan Friendship Highway Project, Japan became the Philippines' largest source of ODA (Camacho Jr. e Cuevas, 2004). According to data published by the Organization for Economic Co-operation and Development (2018), Japan was still the first main donor of gross ODA for the Philippines between 2016 and 2017 (Organization for Economic Co-operation and Development, 2019). More recently, a bilateral agreement between the Ministry of Environment of Japan and the Department of Environmental Natural Resources of the Philippines was established to support the introduction of Waste-to-Energy (WtE) in the Philippines, a technology of waste incineration with energy generation. However, before providing financial aid for technology acquisition and installation, it is essential to improve general waste management conditions, such as waste sorting and collection, to bridge this gap between basic waste infrastructure and the implementation of WtE.

In this context, the relationship between the cities of Kitakyushu and Davao initiated in 2014, when the Japanese company Nippon Steel Corporation, along with experts from KITA, started to promote feasibility studies for the implementation of WtE technology in Davao. Davao City is a large, populated city, that produces 600 to 700 thousand $\mathrm{kg}$ of waste per day. The JICA Grassroots Project for Enhancing Solid Waste Management in Davao City, funded by JICA for the fixed term from April 2017 until March 2020, was the project scheme that resulted from the two cities' effort of improving waste management practices in Davao. The main focus of this project was to enhance capacity building for the staff in City Environment and Natural Resources Office (CENRO), Davao City department responsible for waste collection and treatment, and for the staff in barangays, the smallest administrative division in the Philippines, responsible for waste sorting and collection. KITA and IGES were responsible for providing the workshops and training to enhance municipal solid waste planning and management. By the time of the interviews, as the end of the first funding term was approaching, the project was being prepared for funding renewal.

These collaboration activities for improving the waste management conditions in Davao were the beginning of the relationship between the two cities, and the ignition for the network building between stakeholders in both cities. In 2017, Mayor Kitahashi and Mayor Sara signed a Green Sisters Agreement between Kitakyushu and Davao, tightening this connection and recognizing the importance of such intercity cooperation at the mayor level.

One year later, The City-to-City Collaboration Programme for Low-Carbon Society (C2C) between Kitakyushu and Davao has started. MOEJ launched the C2C scheme in 2013 to promote international cooperation activities at the local level to support the development of low-carbon initiatives in partner developing cities overseas, by transferring management experience from Japanese cities and technology for GHG emission reduction from Japanese companies. The program provides funding for one year, with the possibility of renewal, and aims to help developing countries promote leapfrog development: instead of developing into a high carbon-consuming society, cities will be able to develop while taking a more sustainable path (Ministry of Environment of Japan, 2018). 
In the case of Kitakyushu and Davao, two projects were conducted under the C2C scheme since the fiscal-year of 2018 (renewed for the following year): the development of a Local Climate Change Action Plan (LCCAP) and the installation of LED streetlights in Davao. The development of a LCCAP required three steps: summarizing the data about the amount of GHGs emissions within the limits of Davao; once the inventory is finished and the analysis of each sectors' contribution, stakeholders must target the areas with the largest emissions and discuss possible mitigation recommendations; and discussion on adaptation measures. The introduction of the LED streetlights project was motivated by the fact that there were over 40,000 streetlights with sodium lamps in Davao, so a Japanese company was providing samples of the LED lamps to be tested by the private company Davao Light Power Company.

In summary, this case study comprises of three projects in two schemes (table 1): JICA Grassroots Project for Enhancing Solid Waste Management in Davao City, C2C project for the development of a Local Climate Change Action Plan, and $\mathrm{C} 2 \mathrm{C}$ project for implementation of LED streetlights.

Table 1. Overview of the case study's projects

\begin{tabular}{|l|l|l|l|}
\hline & JICA Grassroots Project & $\begin{array}{l}\text { C2C for development of LCCAP } \\
\text { project }\end{array}$ & $\begin{array}{l}\text { C2C for implementation } \\
\text { of } \begin{array}{l}\text { LED } \\
\text { streetlights }\end{array}\end{array}$ \\
\hline $\begin{array}{l}\text { Funding } \\
\text { agency }\end{array}$ & JICA & MOEJ & MOEJ \\
\hline Objective & $\begin{array}{l}\text { To promote technical support for } \\
\text { the improvement of general } \\
\text { waste management conditions } \\
\text { (sorting and collection, at first) }\end{array}$ & $\begin{array}{l}\text { To promote technical support for } \\
\text { calculation of local greenhouse gas } \\
\text { emissions and implementation of a } \\
\text { city plan for climate action }\end{array}$ & $\begin{array}{l}\text { To promote technology } \\
\text { transfer for installation } \\
\text { of LED streetlights }\end{array}$ \\
\hline
\end{tabular}

\subsection{Methodological Framework}

This research inquires what drivers or challenges can foster or hinder the consensus-building process among the multi-stakeholders in the context of intercity cooperation for environmental planning, in the light of three collaboration projects between Kitakyushu and Davao. To investigate this question, the research was supported by secondary data from relevant past literature and primary data from semi-structured interviews with key stakeholders involved in one or more of the three referred projects.

Past literature supported the research ground by providing contextual information for relevant topics, including drivers and challenges in international intercity cooperation, collaborative planning, and consensus-building schemes; Japanese local government role in the national strategy for international cooperation, as well as cities' motivations to engage in intercity activities; and history of Kitakyushu's experience with intercity cooperation.

The semi-structured interviews delivered information about the contents of collaboration activities, the profile of involved stakeholders, as well as project drivers and challenges. In 
total, six individual interviews with Japanese stakeholders, one group interview with eight Philippine stakeholders, and one individual interview with a Philippine stakeholder were conducted from October until December of 2019 (table 2). The interviews with Japanese stakeholders, as well as with the group of Philippine stakeholders, who were a delegation in working visit, were scheduled and conducted in person, in Kitakyushu City, at the IGES-KUC office. The interview with interviewee 7 was online, due to geographical unavailability.

Table 2. List of respondents and affiliation.

\begin{tabular}{|c|c|c|}
\hline & Date of interview & Affiliation \\
\hline Respondent \#1 & 2019, October 17 & Director from AJITE \\
\hline Respondent \#2 & 2019, October 18 & Senior Technical Expert from KITA \\
\hline Respondent \#3 & 2019, October 18 & Programme Director from IGES \\
\hline Respondent \#4 & 2019, October 18 & Research Manager from IGES \\
\hline Respondent \#5 & 2019, October 18 & Programme Manager from IGES \\
\hline Respondent \#6 & 2019, October 19 & Policy Researcher from IGES \\
\hline Respondent \#7 & 2019, December 12 & $\begin{array}{l}\text { Field Administration Officer from } \\
\text { Nippon Steel Engineering Group }\end{array}$ \\
\hline Respondent \#8 & 2019, November 12 & $\begin{array}{l}\text { - Officer from Davao City Government } \\
\text { - Economist from Davao City Planning and Development } \\
\text { Office } \\
\text { - Barangay captain } \\
\text { - Barangay Monitoring Assistants from CENRO ( } 3 \text { people) } \\
\text { - Information and Education Campaign member from CENRO } \\
\text { - Field Administration Officer from Nippon Steel Engineering } \\
\text { Group }\end{array}$ \\
\hline
\end{tabular}

The interview procedure was oriented by the following sequence: after introducing myself and this research topic, it was required interviewees' consent to record the interview and to make use of the data for research purposes only. Interviewees required confidentially about their names, which was properly respected and followed in this paper. In the sequence, the questions were posed for interviewees to respond freely. After interviews, which lasted about one hour on average, the records were transcribed and analyzed according to the objectives and research question.

The questionnaire for the interviews was organized into three settings of questions. The first set investigated the scope and details of intercity projects between Kitakyushu and Davao in which interviewees were involved (questions about projects were tailored to each interviewee according to their involvement and knowledge); in-depth interviews were valuable to improve the overall comprehension of the collaboration activities, since the case study covered on-going projects and, by the time of this research, information about projects was not yet published. The second set inquired about agents' interests, strengths, and weaknesses, as well as interviewees' perception of the relationship among different groups of stakeholders. 
The third set focused on the drivers and challenges of the projects, as well as recommendations for prospective actions. While the first set of questions focused on information about projects, the second and third sets focused on interviewees' opinions, perceptions, experience, and personal evaluation of collaboration activities.

In sum, semi-structured interviews delivered a vast range of data about projects and involved stakeholders in this case study. In the next session, the major drivers and challenges for consensus building and project making, according to interviewees, will be presented and discussed.

\section{Results - Drivers and Challenges Consensus Building and Project Making}

As interviewees provided information about the projects and their own experience with environmental project-making and intercity cooperation, the elements that can foster or hinder collaborative activities in this case study were identified. Thus, the drivers and challenges from the perspective of stakeholders from both cities were assembled and divided into four groups: communication, political and institutional, financial, and technical. Each of these will be detailed hereinafter.

\subsection{Communication Drivers and Challenges}

Communication was considered by the interviewees as one of the main elements for the success of intercity collaborative activities. For all three projects, it was observed that the speed of negotiations is closely related to the interpersonal familiarity between stakeholders from both cities, and this speed tends to quicken with each new project. For the first term of the JICA Grassroots Project, the stakeholders established the first connections from May 2015 , but only started receiving funding and conducting the project in 2017 . In the sequence, for the first year of the C2C Programme scheme, in 2018, stakeholders seized the opportunity of previous connections and expanded them, so negotiations before receiving the letter of intent from Davao to apply for the MOEJ fund took two months. The second year of the C2C Programme in 2019 was the continuation of last year's activities, so negotiations before preparing the letter of intent took only one to two weeks.

In international collaboration activities such as this case study, usually, most of the time, the stakeholders are geographically apart, so making use of virtual instruments of communication is essential for the maintenance of the relationships and the continuity of the project. However, online communication was mainly limited as a tool for logistics issues, such as selecting participants for study tours, setting mission dates, and organizing details of events. For the discussion about the project contents, guidelines to be followed for the LCCAP, calculation of LED technology price, or even development of relationships, stakeholders prefer face to face meetings and a few hours, even days of dialogue.

Interviewees informed not using video call software for long-distance communication between both cities, so the official communication channel was email. However, it was observed that Japanese and Philippine stakeholders have distinct routines regarding the use of email: while the Japanese agents use email in the daily life and promptly reply to it, the Philippine agents primarily utilize the Facebook Messenger and take a long time to reply to 
the email. To solve this issue, the stakeholders agreed on using email for official communication, and Facebook Messenger as a reminder, follow-up, or confirmation that an email was received.

During the interviews, interviewees were inquired about their perception and evaluation about the communication between stakeholders, considering three aspects: openness between agents, the existence of conflict, and differences between Japanese and Philippine communication.

As for the openness of the communication between stakeholders, both sides declared they felt comfortable about presenting their ideas and perspectives. Japanese interviewees responded that, on one hand, staff from CENRO and barangays are usually very friendly and receptive; on the other hand, Philippine stakeholders might be reluctant in expressing their opinions if a project does not match with their mayor's intention and it would be better if Davao agents were more proactive on proposing new scope for future projects. Philippine interviewees were quite satisfied with the communication with Japanese partners, for their rapid response, for the long-distance support, and the honesty in the dialogue between the two cities.

As for the existence of conflict, Japanese interviewees informed that there was no major conflict between the stakeholders, as the basic framework was agreed in conformity with the funding requirements. Besides, the common goal is to produce good outcomes for Davao City with the collaboration, so there was no hampering disagreement of interest between stakeholders. However, a few cases of conflicts were described, involving the challenge of adjusting the project scope to the political interests and influences in Davao. In Kitakyushu, the city government staff transfer was also identified as a challenge, since new officers require time to get familiar with the projects. Philippine interviewees did not refer to major conflicts, as both sides are very respectful towards each other and the discussions are always smooth, although they mentioned that there were backlogs in the projects due to delayed communication.

Lastly, interviewees explained some differences between the communication among stakeholders from the same or different nationalities. Despite the Philippine agents' lower promptness to reply, Japanese interviewees responded that communication is fine due to openness and English fluency in Davao (which frequently is not the case for other Asian partners). Nevertheless, the communication between Japanese agents, who share a similar knowledge, background, and understanding, is much faster than the communication between Japanese and Philippine agents, which requires more time to build common grounds. Philippine interviewees had replied that, among them, especially among members of Davao City government, the communication is efficient and quick, because city officers tend to have a cooperative attitude towards each other; furthermore, internal communication among city officers is done by an app developed by the city government's IT sector, and they receive a specific allowance for private mobile data. Philippine agents have also referred that the communication with Japanese agents reveals different cultures, working habits, and priority schedules between the cities, but the differences do not hinder cooperation, as stakeholders are willing to establish an inclusive and frank dialogue. 
As referred by past literature, open, participatory communication helps to reach a common understanding of the problem dimension and potential solutions and also enhances the awareness about local needs and specifications, including priorities, strengths, and limitations of each stakeholder in the context of collaborative planning. Communication is an important tool for stakeholder commitment, relationship building and maintenance, and mutual learning. The interviews demonstrated that stakeholders' willingness to establish a participatory dialogue that allows a respectful exchange of ideas could overcome cultural differences, as communication enhanced each others' understanding of cultural, political, institutional, and social differences.

\subsection{Political and Institutional Drivers and Challenges}

Political leadership and commitment are very important drivers to promote international intercity cooperation. In the case of Davao, the political conditions were overall favorable to collaborative planning and action. First, by the time of the interviews, Sara Duterte was the mayor of Davao City and her father, Rodrigo Duterte, was the president of the Philippines, meaning that there was a strong political connection between the city and the national government. Second, mayor Sara was reelected in the elections of May 2019, the second year of collaboration activities between Kitakyushu and Davao, which favored the continuation of activities, as opposition parties' empowerment might change or interrupt project started by the former government. Third, mayor Sara and mayor Kitahashi had been nurturing a friendly relationship, while regularly meeting to discuss projects and foster trust between them. Forth, while mayor Sara was being encouraged to become the next successor for the presidency, she also had her brother as a possible successor in the city government, so political stability in Davao is expected to continue in the next years.

However, despite this favorable political context, interviewees presented some political challenges. In the Philippines, barangay is the smallest administrative division of a government and it lies under the city government. There are 182 barangay in Davao and each one is headed by a captain, elected every four years. Some captains will follow city recommendations and orders, but some are less cooperative, especially from opposite parties. Since the JICA's waste project also included activities and capacity-building for barangay staff, as they are responsible for waste collection, some captains are afraid to implement waste separation, as it might be an unpopular measure that could drop their public support and votes.

As for the institutional arrangement, the favorable aspect of the case study, especially for the $\mathrm{C} 2 \mathrm{C}$ scheme, was that international collaboration activities were supported by a highly-ranked focal point, which is Davao's assistant city administrator, forth in the hierarchy of the city government. This person was strongly connected to local stakeholders from various sectors, and his position was above all city offices, which enabled the coordination among them. Furthermore, this officer, as well as other city staff members, nurtures a high environmental awareness, which also benefits the engagement of involved stakeholders in the collaboration activities.

However, for the development of LCCAP, lack of institutional arrangement was one of the 
main challenges for the first year, when the leading goal was to create the GHG inventory. Although the city staff was optimistic and committed to the project, there was no resource mobilization, specific human resources power allocation, or systematically organized data at the local level to investigate which sectors are the main responsible for GHG emissions.

\subsection{Financial Drivers and Challenges}

The financial perspective is another important element, as the lack of financial resources can hinder project planning and action. Even if funding opportunities can be provided by other organizations, such as the Asian Development Bank and the World Bank, access to regular funding opportunities from the JICA and the MOEJ is a preliminary condition for the project feasibility. Still, financial challenges were recognized in the three projects of this case study.

For the JICA Grassroots project, lack of budget was an overall challenge for Davao. The collaborative activities focused on raising awareness about waste separation, but the city government deals with a limited budget, which affects, for example, the availability of vehicles for waste transportation or basic infrastructures, such as paved roads, recyclable material storage, and other facilities for waste management. Furthermore, the vulnerable social conditions of a large share of the population and the need for even more basic social demands might also hinder public action and support.

For the $\mathrm{C} 2 \mathrm{C}$ Programme projects, the financial challenge faced by agents was the disruption of the funding provision. For this scheme, usually, the MOEJ publishes two calls for proposals: the first call receives proposals from both newcomers and existing project cases, which means that the competitive rate is higher; and the second call accepts proposals only from existing projects. For the Fiscal Year of 2019, Kitakyushu's proposal was rejected in the first call and, after MOEJ's feedback and proposal revision, it was accepted in the second call. For this reason, the stakeholders only received funding for the second half of 2019, and this gap in business trips and face-to-face meetings affected the progress of the collaborative activities.

Also, particularly for the project of the LED lights implementation, although subsidy from the Japanese National government can be provided for low-carbon technology transfer, the Japanese technology is still considered expensive by developing countries, so purchase might still be a challenge. Therefore, in this case, and similar situations of technology transfer, Japanese companies must make an effort to reduce the cost and adjust to the market in developing countries.

\subsection{Technical Drivers and Challenges}

Since the technical aspect is related to technology transfer conditions, the main technical driver in this case study was the flexibility of the Japanese technology provider, to adjust the product to local needs and requirements, including the reduction of production costs. Especially for the installation of LED lights, the selected private company in Kitakyushu, which was not revealed by the interviewees, developed and shipped four samples of lamps to the lighting company in Davao that was responsible for testing. 


\section{MInstitute ${ }_{\text {Mnk }}^{\text {Macrothink }}$}

The JICA project, on the other hand, faced many technical challenges. Although there is an agreement between the Japanese and Philippine governments to transfer WtE technology, such a high technology requires a long term preparation and specific actions before the installation. Improving overall waste management conditions, such as the establishment of waste sorting and collection on a regular basis, is an extensive and time-consuming challenge. Besides, it is necessary to develop legal standards for waste management, as well as settle legal requirements to prepare the area for installation, such as the documents to convert certain land into WtE zone.

Additionally, there is a technical challenge, related to the financial aspect of the $\mathrm{WtE}$ operation. Although an ODA grant will be provided to build such $\mathrm{WtE}$ facility, there are obstacles related to operation maintenance. Who has the technical expertise to operate, what waste specifications fit the facility requirements, and how to maintain the WtE activity are some of the questions that need to be addressed by the stakeholders. Particularly about the waste suitability for the $\mathrm{WtE}$ facility, one of the challenges is that, in the developing countries, waste is usually too wet for incineration, due to the high percentage of kitchen waste, which means that the calorific value is low and the waste is not easily burnable. Although adding extra crude oil to adjust the calorific value might increase the burning capacity, it is not advisable, because it produces carbon dioxide and a characteristic black smoke, which is likely to instigate a high public opposition. In contrast, waste in Japan has a large amount of papers and plastics, with less kitchen waste, so the calorific value is high and the waste is fairly burnable.

Still related to possible problems within operation maintenance, although funding will be provided for technology transfer and facility installation, stakeholders, WtE activities are expensive and require sustainable planning. The feasibility of some ideas, such as the application of a tipping fee or selling the revenue of generated energy, must be carefully discussed and drafted.

\section{Discussion and Conclusion}

Building consensus in a multi-stakeholder scheme is a complex, time-consuming process to reach an agreement of shared understanding about a certain problem and what are the possible ways to address it. The presence of multiple perspectives and backgrounds requires open and respectful dialogue, with the full involvement of stakeholders within their capacities, with a deep investigation of their demands and priorities. Collaborative planning in international intercity cooperation is a frame that requires careful consensus-building development, as it approaches stakeholders with diverse concerns, culture, language, ethnicity, religion, and socioeconomic background, standing in distinct political, legal, and institutional arrangements.

Nonetheless, beyond the challenge of connecting such a diversity of views, a multifaceted group of stakeholders brings to the table a great variety of ideas to be discussed and explored. Convening such a variety of stakeholders, who are willing to sit at the same table and discuss until reaching a common agreement and a joint solution, has proven to be a fruitful learning opportunity for involved agents from both, developed and developing cities. Actors can 
bridge different points of view, enhancing the comprehension of a certain problem, and to share information, knowledge, technologies, and governance experience to address environmental management issues.

During the last decade, the Japanese government, one of the largest world's donors of gross ODA, has been increasing the funding activities to promote intercity collaboration for the development of more sustainable societies, engaging multiple stakeholders for a wide diversity of projects. This research had selected three ongoing international projects, between the Kitakyushu and Davao, and identified major drivers and challenges that affected the collaboration activities among stakeholders from both cities.

The referred case study demonstrated that the availability of previous connections and successful past cases of intercity cooperation was an incentive to expand the scope of collaboration, to involve a larger number of stakeholders, and to increase the credibility of practitioners and their projects. The first collaboration activities required a longer time for individuals to adjust to the new tasks and responsibilities, as well as to foresee potential outcomes of such a project. As, gradually, the relationships were developing and spreading, the roles and possibilities for each stakeholder group also became more clear, and the results were progressively being achieved. Subsequent activities grew over previous connections and were more smooth and quick to develop.

This research grouped four sets of drivers and challenges, as follows: communication, political and institutional, financial, and technical. However, since trust and mutual understanding among the stakeholders is a process of constant construction and maintenance for a multi-stakeholder, collaborative planning scheme, communication was considered by the respondents as the most critical driver for international cooperation, as it is the basis of consensus building, action planning, and conflict resolution processes.

In other words, communication was the minimum ground for all other activities. When so many stakeholders with particular profiles and priorities assemble, sometimes one group's interests and needs are not visible from the very beginning by the others. The initially weak connection between stakeholders could inhibit the free expression of their opinions or stances, but establishing open lines of communication were developed over time, in face-to-face meetings, events, casual meals, and other opportunities that enhance trust-building, warming up, and familiarity among participants.

An inquiry that was raised during this research was why making use of the consensus-building theory over a case study in which the stakeholders already agreed to a certain extent, more specifically to the framework required by the funding agencies. It is important to remember that consensus building is not reached at the end of the collaborative activities but in each project step. Even if stakeholders agree on the basic project conditions and hold no enmity against each other, small conflicts are likely to arise during the process as stakeholders learn about each others' interests, priorities, and perspectives about the nature of the problem or the most preferable solution. Moreover, consensus-building processes benefit stakeholders who are willing to resolve their conflicts and match their interests in a win-win situation. Therefore, a certain level of agreement is a condition for engaging in a 
consensus-building scheme, because, if there is too much discomfort, dislike, or mistrust among stakeholders, reaching consensus is unlikely to be feasible.

This research met some difficulties. The first challenge relates to the chosen case study. Since the projects were still ongoing, there was less information and input available about the tangible outcomes of collaborative activities. The continuity and sustainability of the projects also could not be observed in this short time frame, since, by the time of the interviews, the projects had not reached the final implementation phase.

The second challenge refers to the gaps left by this research, which could be the object of future studies. As further progress and development were expected in the case of collaboration for Kitakyushu and Davao after the conducted interviews, new aspects of consensus-building drivers and challenges might be unfolded by the stakeholders. Another gap was the limitation of the contents of the interviews. The members from the LED lights technology provider, the Davao Light Power Company, and the WtE company in Japan could not be interviewed, so the research mainly reflected the perspective of public sectors and lacked representation from the private sector. Besides, most Philippine representatives only spoke in the group interview, so comments seemed limited to the group's official position, with few declarations of individual perspectives and opinions.

It is recommended that future research further advance on aspects and variables that can foster or hinder the consensus-building process in multi-stakeholders collaboration schemes. Prospective studies can address perspectives from other case studies, within and beyond environmental management cases, or from the other phases of these projects, which will include elements that affect project implementation and evaluation.

The relevance of this research is not limited to this very case study, let alone to environmental projects, as it can contribute to the understanding of other cases of international intercity cooperation as well. Building consensus among multiple stakeholders is in increasing demand, as the international community and emergent stakeholders seek more partnerships, more decentralization of the decision-making and planning processes, and more diversification and innovation in the policy process. Although a case study like this has its particularities, context, and conditions, this research can contribute to future literature by improving the understanding of essential aspects of consensus-building processes, and can help practitioners by highlighting the major influences that require their attention in similar schemes.

\section{Acknowledgments}

This research acknowledges the qualified counseling of my former supervisor Professor Makoto Usami, from the laboratory of Global Environmental Policy of Kyoto University, and the careful support of Programme Director Shiko Hayashi, from the Institute for Global Environmental Strategies. This research also acknowledges the relevant inputs from my former laboratory colleagues, who assisted my research development from 2017 until 2020, and the thoughtful revision of this manuscript by my dear family and friends. My sincere gratitude to all. 


\section{References}

Akagi, J., Kataoka, Y., Hayashi, S., Hibino, K., Ota, J., \& Nuzir, F. A. (2018). Actions for a Sustainable Society - Collaboration between Asia and the City of Kitakyushu. Institute for Global Environmental Strategies. [Online] Available:

https://iges.or.jp/en/pub/actions-sustainable-society-collaboration/en

Ayala-Orozco, B., Rosell, J. A., Merçon, J., Bueno, I., Alatorre-Frenk, G., Langle-Flores, A., \& Lobato, A. (2018). Challenges and Strategies in Place-Based Multi-Stakeholder Collaboration for Sustainability: Learning from Experiences in the Global South. Sustainability, 10(9), 3217. https://doi.org/10.3390/su10093217

Bontenbal, M. C. (2009). Strengthening urban governance in the South through city-to-city cooperation: Towards an analytical framework. Habitat International, 33(2), 181-189. https://doi.org/10.1016/j.habitatint.2008.10.016

Booher, D. E. (2005). Collaborative Governance Practices and Democracy. National Civic Review, 93(4), 32-46. https://doi.org/10.1002/ncr.69

Buis, H. (2009). The role of local government associations in increasing the effectiveness of city-to-city cooperation. Habitat International, 33(2), 190-194.

https://doi.org/10.1016/j.habitatint.2008.10.017

Camacho Jr., J. V., \& Cuevas, A. C. (2004). The Dynamics of Philippines-Japan Economic Cooperation: The Case of Japan's Official Development Assistance (ODA) in the Philippines. Philippine Institute for Development Studies. [Online] Available:

https://www.researchgate.net/publication/24110933_The_Dynamics_of_Philippines-Japan_E conomic_Cooperation_The_Case_of_Japan's_Official_Development_Assistance_in_the_Phil ippines

Carpenter, S. (1999). Choosing appropriate consensus building techniques and strategies. In L. Susskind, S. McKearnan \& J. Thomas-Larmer (Eds.), The consensus building handbook. A comprehensive guide to reaching agreement. Thousand Oaks, Calif, Sage Publications, Chapter 1. https://doi.org/10.4135/9781452231389.n2

Connick, S., \& Innes, J. (2001). Outcomes of Collaborative Water Policy Making: Applying Complexity Thinking to Evaluation. Journal of Environmental Planning and Management, 46(2), 177-197, https://doi.org/10.1080/0964056032000070987

Cullen, D., Mcgee, G. J. A., Gunton, T. I., \& Day, J. C. (2010). Collaborative Planning in Complex Stakeholder Environments: An Evaluation of a Two-Tiered Collaborative Planning Model. Society and Natural Resources, 23(4), 332-350.

https://doi.org/10.1080/08941920903002552

De Villiers, J. C. (2009). Success factors and the city-to-city partnership management process - from strategy to alliance capability. Habitat International, 33(2), 149-156.

https://doi.org/10.1016/j.habitatint.2008.10.018

Fuhr, H., Hickmann, T., \& Kern, K. (2018). The role of cities in multi-level climate 
governance: local climate policies and the $1.5 \mathrm{C}$ target. Current Opinion in Environmental Sustainability, 30, 1-6. https://doi.org/10.1016/j.cosust.2017.10.006

Gunton, T. I., Peter, T., \& Day, J. C. (2006). Evaluating Collaborative Planning: A Case Study of a Land and Resource Management Planning Process. Environments Journal, 34(3), 19-37. [Online] Available:

https://www.researchgate.net/publication/265321023_Evaluating_Collaborative_Planning_A _Case_Study_of_a_Land_and_Resource_Management_Planning_Process

Huda, M. I. M. (2016). Evolution of Japanese ODA 1945-2015: An Analysis. International Journal of East Asian Studies, 5, 14-28. [Online] Available:

https://www.researchgate.net/publication/311856131_Evolution_of_Japanese_ODA_1945-20 15_An_Analysis

Innes, J. E., \& Booher, D. E. (1999). Consensus Building and Complex Adaptive Systems A Framework for Evaluating Collaborative Planning. Journal of the American Planning Association, 65(4), 412-423. https://doi.org/10.1080/01944369908976071

Innes, J. E., \& Connick, S. (2001). Consensus Building as a Policy Making Strategy for Water Resources Management. UC Berkeley: University of California Water Resources Center. [Online] Available: https://escholarship.org/uc/item/7851k1kn\#main

Innes, J. E. (2004). Consensus building: clarification for the critics. Planning Theory, 3(1), 5-20. https://doi.org/10.1177/1473095204042315

Innes, J. E. (2011). Coordinating Growth and Environmental Management Through Consensus Building, Vol. 1. UC Office of the President: California Policy Research Center. [Online] Available: https://escholarship.org/uc/item/308983c0

Ishinabe, N. (2010). Analysis of international city-to-city cooperation and intercity networks for Japanese national \& local governments. Institute for Global Environmental Strategies. [Online] Available: https://iges.or.jp/en/pub/analysis-international-city-city-cooperation/en

Kato, H. (2016). Japan's ODA 1954-2014: Changes and continuities in a central instrument in Japan's foreign policy. In H. Kato, J. Page, \& Y. Shimomura (Eds.), Japan's Development Assistance. Palgrave Macmillan, London. https://doi.org/10.1057/9781137505385_1

Kurniawan, T. A., de Oliveira, J. P., Premakumara, D. G. J., \& Nagaishi, M. (2013). City-to-city level cooperation for generating urban co-benefits: the case of technological cooperation in the waste sector between Surabaya (Indonesia) and Kitakyushu (Japan). Journal of Cleaner Production, 58, 43-50 https://doi.org/10.1016/j.jclepro.2013.08.002

Liu, L. A., Barry, B., Friedman, R., \& Gelfand, M. (2012). The dynamics of consensus building in intracultural and intercultural negotiations. Administrative Science Quarterly, 57(2), 269-304. https://doi.org/10.1177/0001839212453456

Margerum, R. D. (2002). Collaborative planning: building consensus and building a distinct model for practice. Journal of Planning Education and Research, 21(3), 237-253. https://doi.org/10.1177/0739456X0202100302 


\section{Macrothink}

Environmental Management and Sustainable Development

ISSN 2164-7682

2020, Vol. 9, No. 4

Margerum, R. D. (2008). A Typology of Collaboration Efforts in Environmental Management. Environmental Management, 41, 487-500. https://doi.org/10.1007/s00267-008-9067-9

Margerum, R. D. (2011). Beyond Consensus: Improving Collaborative Planning and Management. MIT Press Scholarship Online.

https://doi.org/10.7551/mitpress/9780262015813.001.0001

Markopoulos, M. (2012). Collaboration and multi-stakeholder dialogue. A review of the literature. International Union for Conservation of Nature and Natural Resources. [Online] Available: https://www.iucn.org/content/collaboration-and-multi-stakeholder-dialogue-a-revie w-literature

Memon, M. A., Pearson, C., \& Imura, H. (2005). Inter-city Environmental Cooperation: The Case of the Kitakyushu Initiative for a Clean Environment. International Review for Environmental Strategies, 5(2). [Online] Available:

https://iges.or.jp/en/pub/inter-city-environmental-cooperation-case/en

Ministry of Environment of Japan. (2018). City-to-City Collaboration for Low-Carbon Society - 2018. Ministry of Environment of Japan. [Online] Available:

https://www.env.go.jp/earth/coop/lowcarbon-asia/english/project/data/jcm_pamphlet_C2C_2 018_EN.pdf

Ministry of Foreign Affairs of Japan. (2004). The View on the Japanese ODA in the Recipient Countries. Ministry of Foreign Affairs of Japan. [Online] Available:

https://www.mofa.go.jp/policy/oda/cooperation/anniv50/seminar0411.txt

Morse, R. S., \& Stephens, J. B. (2012). Teaching Collaborative Governance: Phases, Competencies, and Case-Based Learning. Journal of Public Affairs Education, 18(3), 565-584. https://doi.org/10.1080/15236803.2012.12001700

Nakamura, H. (2010). Enhancing low-carbon development through international co-operation between cities in Japan and in Asian developing countries: Roles and activities for an international platform on low-carbon cities in Asia. Institute for Global Environmental Strategies. [Online] Available:

https://iges.or.jp/en/pub/enhancing-low-carbon-development-through/en

Nakamura, H., Elder, M., \& Mori, H. (2010). Explaining international environmental co-operation by Japanese municipal governments with developing countries. Institute for Global Environmental Strategies. [Online] Available:

https://iges.or.jp/jp/pub/explaining-international-environmental-co/en

Nakamura, H., \& Elder, M. (2012). Practical measures to promote Japanese local governments' environmental collaboration with developing countries with citizens' support. Institute for Global Environmental Strategies. [Online] Available:

https://www.iges.or.jp/en/pub/practical-measures-promote-japanese-local/en

Organization for Economic Co-operation and Development. (2019). Top ten donors of Gross ODA for Philippines. [Online] Available: 


\section{Macrothink}

Environmental Management and Sustainable Development

ISSN 2164-7682

2020, Vol. 9, No. 4

http://www.oecd.org/dac/financing-sustainable-development/development-finance-data/aid-at -a-glance.htm

Ohno, I. (2013). Japan's ODA Policy and Reforms since the 1990s and Role in the New Era of Development Cooperation. Journal of International Development Cooperation, 8(4), 64-94. https://doi.org/10.34225/jidc.2013.4.64

Ohno, I. (2014). Japanese Development Cooperation in a New Era: Recommendations for Network-Based Cooperation. National Graduate Institute for Policy Studies Discussion Paper 14-15. [Online] Available:

http://www.grips.ac.jp/forum/IzumiOhno/lectures/2015_Lecture_texts/03_IO_GRIPSdiscussi onpaper.pdf

Rosseel, P., De Corte, E., Blommaert, J., \& Verniers, E. (2007). Approaches to North-South, South-South and North-South-South Collaboration: A policy document. [Online] Available: https://www.academia.edu/29734002/Approaches_to_North-South_South-South_and_NorthSouth-South_Collaboration_A_policy_document_Content

Sawada, Y. (2014). Japan's Strategy for Economic Cooperation with Asian Countries. Public Policy Review, Policy Research Institute, Ministry of Finance Japan, 10(1), 53-76. https://warp.da.ndl.go.jp/info:ndljp/pid/11217434/www.mof.go.jp/english/pri/publication/pp_ review/ppr024/ppr024c.pdf

Schreurs, M. A. (2010). Multi-level Governance and Global Climate Change in East Asia. Asian Economic Policy Review, 5, 88-105. https://doi.org/10.1111/j.1748-3131.2010.01150.x

Susskind, L. (1999). An alternative to Robert's rules of order for groups, organizations, and ad hoc assemblies that want to operate by consensus. In L. Susskind, S. McKearnan \& J. Thomas-Larmer (Eds.), The consensus building handbook. A comprehensive guide to reaching agreement. Thousand Oaks, Calif, Sage Publications, Part 1.

https://doi.org/10.4135/9781452231389.n1

Susskind, J. E., Fuller, B. W., Ferenz, M., \& Fairman, D. (2002). Multistakeholder Dialogue at the Global Scale. Working Paper, Consensus Building Institute.

https://doi.org/10.1163/157180603322576121

Susskind, L., Camacho, A. E., \& Schenk, T. (2010). Collaborative Planning and Adaptive Management in Glen Canyon: A Cautionary Tale. Columbia Journal of Environmental Law, 35, 1. [Online] Available:

https://scienceimpact.mit.edu/sites/default/files/documents/Collaborative\%20Planning\%20an d\%20Adaptive\%20Management\%20in\%20Glen\%20Canyon-\%20A\%20Cautionary\%20Tale. pdf

Takao, Y. (2014). Local Levels of Participation in Japan's Foreign Aid and Cooperation. Asian Survey, 54(3), 540-564. https://doi.org/10.1525/as.2014.54.3.540

Takao, Y. (2017). Subnational participation in extra-national policy solutions: Kitakyushu City as an intermediate agent in policy coordination. The Pacific Review, 30(4), 596-614. 


\section{Macrothink \\ Environmental Management and Sustainable Development \\ ISSN 2164-7682 \\ 2020, Vol. 9, No. 4}

https://doi.org/10.1080/09512748.2017.1282537

Tjandradewi, B. I., \& Marcotullio, P. J. (2008). City-to-city networks: Asian perspectives on key elements and areas for success. Habitat International, 33(2), 165-172.

https://doi.org/10.1016/j.habitatint.2008.10.021

United Nations Human Settlements Programme. (2001). City-to-City Cooperation: Issues Arising from Experience. United Nations Human Settlements Programme. [Online] Available: https://proyectoallas.net/wp-content/uploads/2018/01/City-to-City-Cooperation-Issues-Arisin g-from-Experience.pdf

United Nations. (2020). Goal 17: Revitalize the global partnership for sustainable development. [Online] Available:

https://www.un.org/sustainabledevelopment/globalpartnerships/

United Nations Framework Convention on Climate Change. (2015). Adoption of the Paris agreement. United Nations Framework Convention on Climate Change. [Online] Available: https://unfccc.int/resource/docs/2015/cop21/eng/109r01.pdf

Yanagihara, T. (2017). International Trends in Development Aid and Japan's ODA. The Japanese Institute of International Affairs. [Online] Available:

https://www2.jiia.or.jp/en/pdf/digital_library/world/170331_yanagihara.pdf

\section{Copyright Disclaimer}

Copyright for this article is retained by the author(s), with first publication rights granted to the journal.

This is an open-access article distributed under the terms and conditions of the Creative Commons Attribution license (http://creativecommons.org/licenses/by/4.0/). 